\section{COVID-19 pandemic containment: following the example of military submariners}

\author{
Jean-Baptiste Bouillon-Minois 다, ${ }^{1}$ M Trousselard 다, ${ }^{2}$ F Dutheil ${ }^{3}$
}

Since its initial description at the end of December 2019, the new severe acute respiratory syndrome (SARS)-CoV2 epidemic has become a rapidly evolving pandemic. ${ }^{1}$ Following the WHO recommendation, governments worldwide declared quarantine status and containments to prevent the spreading of the disease. At the time of writing, more than 3.5 billion people (half of humanity) are under containment because of coronavirus restrictions $^{2}$ in either their movement, or limitations in the availbility of everyday items. The 20th century saw massive international treaties favouring both circulation of goods (eg, North American Free Trade Agreement, Association of South East Asian Nations and Economic Community Of West African States) and people (Schengen Area). The number of international air travellers has multiplied by 10 in less than 50 years. In this context, containment imposed by the SARS-CoV-2 pandemic is triggering psychological distress. ${ }^{3}$ We believe that military submariners are a potential population for which

\footnotetext{
${ }^{1}$ CNRS, LaPSCo, Physiological and Psychosocial Stress, University Hospital of Clermont-Ferrand, Emergency Medicine, Clermont Auvergne University, ClermontFerrand, France

${ }^{2}$ French Armed Forces Biomedical Research InstituteIRBA, Neurophysiology of Stress, Neuroscience and Operational Constraint Department, IRBA, Bretigny-surOrge, Île-de-France, France

${ }^{3}$ CNRS, LaPSCo, Physiological and Psychosocial Stress, University Hospital of Clermont-Ferrand, Occupational and Environmental Medicine, WittyFit, Clermont Auvergne University, Clermont-Ferrand, AuvergneRhône-Alpes, France
}

Correspondence to Dr Jean-Baptiste Bouillon-Minois, Emergency Medicine, Clermont Auvergne University, Clermont-Ferrand 63001, France; jbb.bouillon@gmail. com to study quarantine and containment measures against. They sleep under the ocean usually between 2 and 3 months at a time, which is currently much longer than the usual containment period undertaken by most countries. Looking at evidence-based data regarding submariners, the specific containment of submariners provides conflicting results for stress. Even if a first study showed higher stress levels in the Royal Navy submariners than in the Royal Navy surface fleet, ${ }^{4}$ a 2 -year cohort study did not confirm those results. ${ }^{5}$ Moreover, despite not seeing the natural sunlight that synchronises the circadian rhythm, there was no alteration of the sleep and wake patterns during a 70 -day routine mission, with sleep monitored by polysomnography. ${ }^{6}$ Furthermore, and maybe the most important, the Royal Naval submariners between 1960 and 1989 seemed to have been a healthy group with low mortality overall. ${ }^{7}$

Twitter Jean-Baptiste Bouillon-Minois @ BouillonJeanBa2

Contributors This correspondence was written during a Skyper session between the three authors. J-BB-M was the main writer and the corresponding author.

Funding The authors have not declared a specific grant for this research from any funding agency in the public, commercial or not-for-profit sectors.

Competing interests None declared.

Patient consent for publication Not required.

Provenance and peer review Not commissioned; internally peer reviewed.

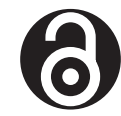

OPEN ACCESS
Open access This is an open access article distributed in accordance with the Creative Commons Attribution Non Commercial (CC BY-NC 4.0) license, which permits others to distribute, remix, adapt, build upon this work non-commercially, and license their derivative works on different terms, provided the original work is properly cited, appropriate credit is given, any changes made indicated, and the use is non-commercial. See: http://creativecommons.org/ licenses/by-nc/4.0/.

(C) Author(s) (or their employer(s)) 2020. Re-use permitted under CC BY-NC. No commercial re-use. See rights and permissions. Published by BMJ.

\section{Check for updates}

To cite Bouillon-Minois J-B, Trousselard M, Dutheil F. BMJ Mil Health 2020;166:362.

Received 16 April 2020

Revised 21 April 2020

Accepted 22 April 2020

Published Online First 4 May 2020

BMJ Mil Health 2020;166:362.

doi:10.1136/bmjmilitary-2020-001501

ORCID iDs

Jean-Baptiste Bouillon-Minois http://orcid.org/00000002-6556-4187

M Trousselard http://orcid.org/0000-0003-0592-4547

\section{REFERENCES}

1 Chan JF-W, Yuan S, Kok K-H, et al. A familial cluster of pneumonia associated with the 2019 novel coronavirus indicating person-to-person transmission: a study of a family cluster. Lancet 2020;395:514-23.

2 Sandford A. Coronavirus: half of humanity on lockdown in 90 countries. Available: https://www.euronews.com/ 2020/04/02/coronavirus-in-europe-spain-s-death-tollhits-10-000-after-record-950-new-deaths-in-24-hou

3 Qiu J, Shen B, Zhao M, et al. A nationwide survey of psychological distress among Chinese people in the COVID-19 epidemic: implications and policy recommendations. Gen Psychiatr 2020;33:e100213.

4 Brasher KS, Dew ABC, Kilminster SG, et al. Occupational stress in submariners: the impact of isolated and confined work on psychological well-being. Ergonomics 2010;53:305-13.

5 Brasher KS, Sparshott KF, Weir ABC, et al. Two year follow-up study of stressors and occupational stress in submariners. Occup Med 2012;62:563-5.

6 Trousselard M, Leger D, van Beers P, et al. Sleeping under the ocean: despite total isolation, nuclear Submariners maintain their sleep and wake patterns throughout their under sea mission. PLoS One 2015;10:e0126721.

7 Inskip H, Snee M, Styles L. The mortality of Royal naval submariners 1960-89. Occup Environ Med 1997;54:209-15. 